\title{
Impact of consumption aspirations and brand knowledge on customer decision making: Evidence form fast food industry of Pakistan
}

\author{
Shaheer Ellahi ${ }^{\mathrm{a}}$, Muhammad Arshad ${ }^{\mathrm{b}}$, Sumaira Shamoon ${ }^{\mathrm{c}}$ and Sadaf Zahoor ${ }^{\mathrm{c}}$
}

${ }^{a}$ Human Resource Development Network Islamabad, Pakistan

${ }^{b}$ University of education Lahore, Pakistan

${ }^{c}$ Riphah International University Islamabad, Pakistan

\section{A R T I C L E I N F O}

\section{Article history:}

Received March 29, 2012

Received in Revised form

June, 18, 2012

Accepted 28 July 2012

Available online

August 12012

Keywords:

Consumption aspirations

Brand knowledge

Customer decision making

\begin{abstract}
The purpose of this research is to find out the impact of consumption aspirations and brand knowledge on customer purchase decisions. Data was collected through a questionnaire from 168 customers of fast food sector of Pakistan. Results show that there is a positive association between consumption aspirations, brand knowledge and customer decision making. The Results of the study show that there is a significant association between consumption aspirations, brand knowledge and customer decision making. The fast food sector can get higher level of customer satisfaction and a higher number of customer base and market share through a higher level of brand knowledge and consumption aspiration of the customer. The results of the study show that there is a positive association between consumption aspirations, brand knowledge and customer decision making in the fast food sector of Pakistan.
\end{abstract}

\section{Introduction}

While designing new products or renewing the old ones, company has to be very conscious about the customer aspirations and preferences. Good companies search for the customer preferences and this matters a lot while designing their products as their products would be according to their customers need (Gilbert, 2006). Developing brand names and creating brand knowledge among the target markets is a critical issue, which has been considered in last few years. A research study conducted in 2002 showed that to develop a strong and successful brand names few decisive factors should be kept in mind including themes of focus, consistency and values which a company carries (Jones et al., 2002). Whenever the question rose about the customer buying behavior or purchase decision many issues are being raised by researchers in the history. A research study showed that whenever a franchise chain like food restaurants, serves a specific niche of their target market, customers are easy 
to mold and if catered properly their expectations can be met easily, thus their purchase decisions can be turned toward one's brand (Liu, 2000).

This paper explores the relationship between consumption aspirations, brand knowledge and decision making of the customer in the fast food industry of Pakistan. The fast food industry is one of the fastest and full of potential growing industries of Pakistan, it has a considerable growth potential and it is also very significant with respect to international market. The trend of food and taste of targeted customers i.e. youngsters is shifting day by day and also globalization is one of the major factors which is causing growth of fast food industry. Fast food is becoming a choice of not only youngsters; it is equally liked by the elders and children. (Pettigrew \& Roberts, 2006). The review of literature shows that customer decision making have not been studied earlier with specific reference to consumption aspirations and brand knowledge by the researches and also in the context of fast food industry (as it is the developing sector). The evidence from the study of (Yi Lin \& Chen, 2006) proves this argument product knowledge and product involvement with specific reference to consumer decision making. However, the sector was different and limitations of the study show that consumption aspirations are important factor contributing in this model. Moreover, Moore and Lehmann (1980) conducted a research on individual differences in search behavior for a nondurable. They identified the importance of information search regarding the required product, which contributes to brand knowledge along with the customer decision making. Newman and Staelin (1972) conducted a study on information search and identified its importance with reference to customer decision making, but the sector was cars and household appliances.

Brucks (1985) conducted a study on the effect of product class knowledge on information search behavior, and found that product knowledge has a positive impact on customer information search behavior, which has an impact on the customer decision making. All these studies provide evidence that the study is having a theoretical importance as there is a lack of research in the specific sector (i.e. fast food). Moreover, the studies on same variables are having a difference, which is sector difference and the combination of variables. There is a little support for the relationship of consumption aspirations and brand knowledge with the purchase decisions of customers, with specific reference to Pakistan there is no evidence of such model. The study is exploratory and aims to explore the relationship of consumption aspirations and brand knowledge with purchase decision of customers.

The findings of the study will be helpful for the strategy development and will help the managers develop customer oriented plans and products which could lead to customer retention and satisfaction. This will help create the long term customer relationship. The purpose of this paper is to find out the impact of consumption aspirations and brand knowledge on the purchase decision of customers with specific reference to three elements (1) need identification (2) information search and (3) final purchase decisions in the fast food sector of Pakistan. The study is aimed to answer the following important questions, which include to what extent customer purchase decision is influenced by consumption aspirations and what is the influence of brand knowledge on purchase decision of the customers.

\section{Literature review}

\subsection{Consumption Aspirations}

Lee and Ulgado (1997) concluded in their research paper that while talking about fast food restaurants and fast food quality, customer aspirations may vary from place to place. For instance, in United States, customers preferences in testing the quality of food is quite different from that of Indians thus it shows that customer aspirations and standards of good and bad food may vary. Customer aspirations and preferences may vary from market to market as in few food chains clients prefer variety, momentum and pleasant staff while in other areas customers would be impressed if 
brand possess low price, uniqueness and easy access (Kara et al., 1995). A customer aspiration is the leading factor when we talk about the buying behaviors because once the customer preferences are caught by the product then their purchase would automatically be the same. However, if they are satisfied then they would have less impact from these TV ads (Kobayashi, 2010).

Customers and their preferences are very important whenever talking about success of any product within a specific culture. In addition, a research study showed that it is very important to dig out the relationship and pairing among two or more products within one culture because if a company fails to follow that pair of product, client's aspirations may bend towards the competitor's product. Therefore, a company needs to find out such relationships and the study takes an example of wine and food to explain the phenomenon (Pettigrew \& Charters, 2006). Marketers and businesses have to consider the customer aspirations and preferences before they make a marketing strategy because customers sometimes would only focus over the product and its attributes. However, at other times, customer may have certain restrictions, which need to be considered by marketers, this may include shortage of time and thus consumption of convenience food would be a preference (Darian \& Cohen, 1995). A research study reported that the trend of single standing home deliveries in fast food was declining. The basic reason behind this was that customers need modification and changes and the competitors also stay away if companies keep on modifying and adding new products to their food stores and restaurants.

This not only gives choices to clients but it also increases their chances of purchase too (Price, 1997). Various researches have been looking at the issues regarding customer aspirations but when we talk about fast food restaurants, the issue becomes more complex. Here the customer would focus very large number of factors while developing their aspirations or preferences and the very common among them is the hygiene and health factor. All such issues were the basic focus of the study done by Dixon et al. (2006). Keeping customer aspirations in mind, many companies do offer a discount coupon whose redemption is at different timings. So here a research study shows the impact of timings and nature of product over these types of coupons and their redemptions. It says that marketers should focus the product category and timings before offering the discounts over fast food items because a wise decision would increase customer's aspirations towards the product very soon (Banerjee \& Yancey, 2010).

\subsection{Brand Knowledge}

Brand knowledge and awareness can be created among customers by using several different ways but the most successful process is by creating an awareness among customers about the best traits of the company, especially the ones which customer would prefer the most. A study showed few points related to brand awareness and they said that by defeating rivalries in the market through intense competition and by highlighting the factors through which have beaten the competitors could also create a strong brand image and awareness in customers mind (Kara et al., 1997). An important study showed that brand awareness is not always a good representation of market leadership; it means that if a product is enjoying the highest brand awareness. One major aspect of brand awareness is the perceived service quality, if perceived quality is good, then it is going to contribute the sales and revenues of a company positively and if it is not good then company is going to suffer low sales (Qin et al., 2010). As discussed earlier brand awareness is such an important factor that a huge analysis is needed before you target your customers for awareness purposes. Now one method is to check the level of customer satisfaction and the major things, which customers want to be changed, this will help the company to target the specific traits of the product which are more important in customers mind (Gilbert et al., 2004).

Nowadays technological innovations are very common at a very fast pace and using these technological tools to create a brand awareness and to improve the services we offer would let our company to entitle a huge number of clients. These technologies may start from cooking techniques, 
flavoring, less energy consumption to marketing strategies (Rodgers, 2008). A comparative study among the south, east and west regions for the consumption of fast food products of a specific brand, specially French fries indicated that the region which showed the highest level of consumption was very well aware of the brand and thus this shows the importance of brand awareness among customers (Fanning et al., 2010). Once the customers become aware of our brand and all its benefits and competitive edges the customers would be more loyal. In a brand awareness survey about the pairing of toys with fast food meals, a research study revealed that the views of people were very conflicting. Few were in favor by saying that their children would have a complete fun time at fast food restaurants but the other group of people were disappointed because the hygiene factor was the main thing for them (Pettigrew \& Roberts, 2006). A lot of research has been conducted on brand awareness and brand knowledge but few have a huge significance over the subject. A research study conducted by Denise showed that even if the brand wants to create a strong good name in public then it has to pass some legal standards because many fast food restaurants have been contributing to the health problems in customers. So to cater such problems agencies are their which control the hygienic conditions of these fast food chains by approving only those who fulfill these standards thus those brand can build their awareness programs afterwards (Worsfold, 2006).

\subsection{Customer Decision making}

Although in marketing terms, it is said that "Customer is always right" but sometimes customers purchase decisions are wrong too. As if we talk about food restaurants and food chains, it can be seen that advertising has twisted the customer choices in such a way that they did not even consider their health, which is very alarming for policy makers and decision makers (Eagle \& Brennan, 2007). "Consumer purchase intention means the possibility and probability of a consumer's willingness to purchase a specific product" (Dodds et al., 1991). Whenever talked about customer buying behavior specially related to food chains a number of studies have been discussed and a research study clarifies that customer decision is not only based on quality of food but it also depends on several other factors. The reason is because clients have mentioned that they want to have fun whenever they plan to have food outside their home (Goyal \& Singh, 2007). It has been observed by the two researchers named Qin and Prybutok (2009 ) that purchase decision of customers is not a sole thing which happens immediately, instead it is a chain of processes which starts with the product quality, product value and then customer satisfaction which leads the customer to the final purchase of the product. So catering all those prerequisites is also very important when we talk about fast food chains (Qin \& Prybutok, 2009). Although consumer purchase decisions are molded by such media pressures but few other facts are also there, like when the customers compare one food product with another they usually consider the health risk involved in it which is usually derived from hygiene factors. Therefore, if the customer finds one product better over the other in such aspect then his purchase decision would automatically be in favor of healthier foods (McCarthy et al., 2006).

A research study conducted in context of dietary aspects gave a complete picture that although fast food chains might be a convenient option for customers but restaurants if start taking care of their customers would add a plus benefit. This would not only create reliability for fast food chains but the myth that "fast food is injurious to health" would also be removed (Davies \& Smith, 2004). A case study conducted on the marketing segmentation gave an overview that how the potential purchase from the customer can be caught once the marketers are aware of the right product for the right customers. Moreover, in the case they took the example of two market segments; tourists and locals and gave the modification and sale pattern for both segments and then changes in their buying decisions were also reported (Dana \& Dana, 1999). As clients have the power so it is very important for the fast food chains who work over the home delivery offers. Research study showed that the system optimization and less time consuming home deliveries makes the customers to purchase the product and to repeat their purchase decisions (Church \& Newman, 2000). Although the purchase decision of customers in favor of the product is very important for the marketers but more important 
thing is the repurchase decision of customers. It means that if the customers come back after initial purchase to repurchase that product then it shows the satisfaction of the client and his desire to purchase the product again and again, (Law \& Zhao, 2004). There is a positive association between brand knowledge and customer purchase decisions (Lin \& Chen, 2006).

\section{Hypothesis}

H1: Consumption aspirations have a significant impact on customer decision making.

H2: Brand knowledge has a significant impact on customer decision making.

\section{Theoretical framework}

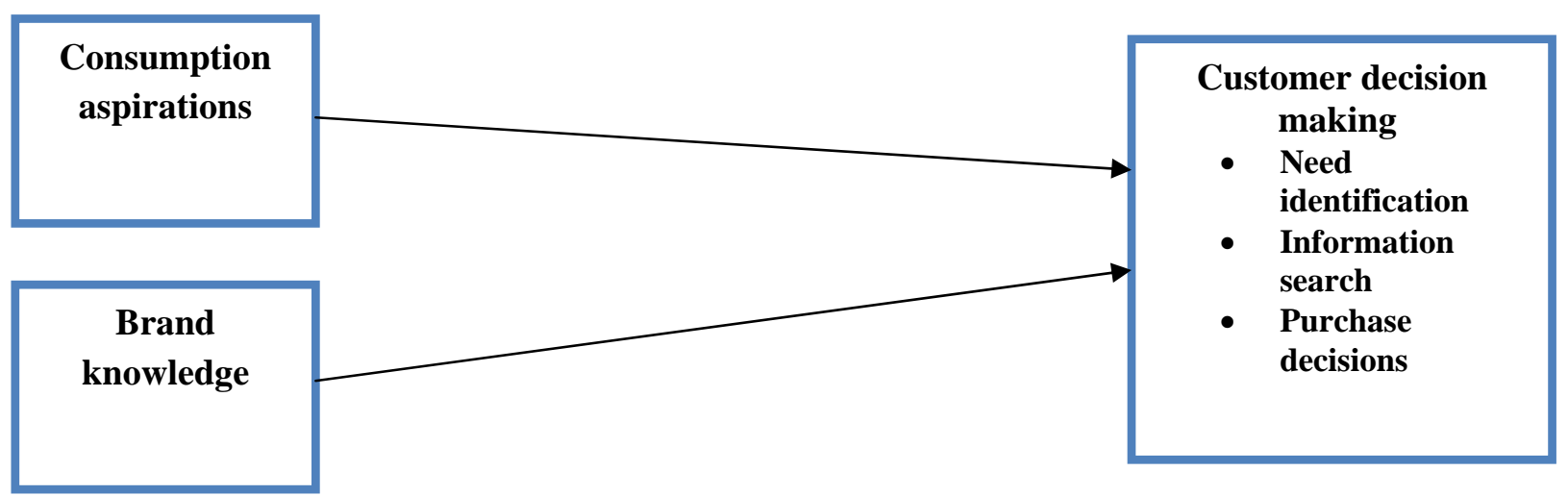

\section{Research Methodology}

\subsection{Research Structure}

In this study as the theoretical framework shows the dependent variable customer decision making and the independent variables are consumption aspirations and brand knowledge.

\subsection{Population}

The targeted population of the study was fast food industry of Pakistan.

\subsection{Sampling Design}

This study was mainly focused on the respondents form fast food industry in main cities of Pakistan. The sample size was 250 respondents as it is most appropriate representative of the total population because the study is a research project, which is short term project so the above mentioned sample can be effectively handled and analyzed. According to Yen (1996) the random sampling technique and convenient sampling technique is effective so in this study random sampling technique has been used. There is an increasing trend in the fast food industry of Pakistan and they are operating in operating in main cities of Pakistan.

\subsection{Sample statistics}

The sample of the study was having following statistical characteristics. This included gender, age, qualification, marital status, educational level, tenure, language, income and other necessary demographic details.

\subsection{Questionnaire Design}

The questionnaire that has been used in this study consists of two major sections. The first section covers up the demographic details of all the respondents whereas the second section consists of items 
related to the variables being measured, which includes consumption aspirations, brand knowledge and customer decision making. The questionnaire is based on five point Likert scale, there are five options on this scale; 1 represents strongly agree, 2 is for agree, 3 is for neutral, 4 is for disagree, 5 is for strongly disagree. All the study variables will be measured using self reported responses because self reporting is considered to be more appropriate for these measures. However to avoid self reporting bias issues, items were measured using customers rated responses. To measure the brand knowledge a five-point scale consisting of seven items has been used. This scale is developed by Lin and Zhen (2005). To measure the information search part of customer decision making variable the scale containing of 4 items has been used this scale is adopted form McQuarrie and Muson (1992). Here, 1 means totally disagree and 5 means totally agree. To measure the purchase decision of the customers the scale of Dodds et al.'s (1991) has been used and it consists of 5 items.

\subsection{Data collection}

Field survey was conducted amongst the customers of fast food industry of Pakistan. The data was collected through self administered questionnaires. The specified sector for this study was the fast food industry, which includes major fast food outlets operating in Pakistan. They include McDonald, KFC and subway etc. These are the brands having a considerable market share and they are in a state of perfect competition so it is important to study the relationship between consumption aspirations, brand knowledge and customer decision making within this sector in Pakistan. The data was collected through reliable and valid questionnaires and the sample size was two hundred and fifty (168). It was a most appropriate sample because this study was a short term study and the above mentioned sample was effective to get appropriate result it has been used in the previous literature.

\subsection{Regression and correlation analysis}

The regression and correlation was run to find out the empirical findings of the study and to find out the fitness of the model and variables.

\section{Results}

Descriptive statistics was obtained for sample descriptions. Descriptive statistics may reveal any of the problem in the data, wrong entry etc. Correlation analysis was done to find Interco relations among study variables. Multiple linear regression analysis technique was used to test Hypothesis. All the data of the study has been analyzed through SPSS (statistical program for social sciences). Reliability tests, regression analysis and correlation analysis were run through this software to find out the empirical findings of the study.

\section{Table 1}

Correlation analysis

\begin{tabular}{llccc}
\hline & & MEANS_CA & MEANS_BN & MEANS_CD \\
\hline MEANS_CA & Pearson correlation & 1 & $0.491^{* *}$ & $0.170^{*}$ \\
& Sig. (2-tailed) & 0.000 & 0.000 & 0.027 \\
& N & 168 & 168 & 168 \\
\hline MEANS_BN & Pearson correlation & $0.491^{* *}$ & 1 & $0.627^{* *}$ \\
& Sig. (2-tailed) & 0.000 & 0.000 & 0.000 \\
\hline MEANS_CD & N & 168 & $0.627^{* *}$ & 168 \\
& Pearson correlation & $0.170^{*}$ & 0.000 & 1 \\
& Sig. (2-tailed) & 0.027 & 168 & 0.000 \\
\hline **. Correlation is significant at the 0.01 level (2-tailed). & 168 & & 168 \\
**. Correlation is significant at the 0.05 level (2-tailed). & & &
\end{tabular}

In the study, correlation analysis shows that there is a significant and positive relationship between consumption aspirations and brand knowledge along with the significant association between these two variables and customer decision making. According to the hypothesis, consumption aspiration is 
significantly correlated $\left(.170^{*}\right)$ with customer decision making. This indicates that consumption aspiration is significantly related with customer decision making. There is a strong association between brand knowledge and customer decision making $\left(.627^{* *}\right)$ the correlation is in expected direction hence supporting the hypothesis 1 and 2 of the study.

Table 2

Model summary

\begin{tabular}{llllllllll}
\hline \multicolumn{10}{c}{ Change Statistics } \\
\hline Model & $\mathrm{R}$ & $\mathrm{R}^{2}$ & ${\text { Adjusted } \mathrm{R}^{2}}^{2}$ & Std. Error & $\mathrm{R}^{2}$ Change & F Change & df1 & df2 & Sig. F Change \\
\hline 1 & .647 & .418 & .411 & .45932 & .418 & 59.271 & 2 & 165 & .000 \\
\hline
\end{tabular}

Table 3

Regression analysis

\begin{tabular}{lllll}
\hline & Beta & T value & Significance & Adjusted R square \\
\hline Consumption aspirations & .202 & 2.663 & .009 & .411 \\
Brand knowledge & .478 & 10.503 & .000 & .411 \\
\hline
\end{tabular}

Regression indicates that the value of $\mathrm{R}^{2}$ is .411 showing that there is $41.1 \%$ variation in customer decision making due to consumption aspirations while 59.9\% remained unexplored. It shows that there some other factors which can affect the decision making of employees. The value of $\mathrm{F}=59.271$ is significant at .000 level while beta value is .202 for consumption aspirations, which is significant at the .009 level. Similarly, brand knowledge is having a beta value of .478 , which means is significant at .000 , the $\mathrm{R}^{2}$ shows that brand knowledge is exploring 41.4 of the total.

\section{Conclusion}

The purpose of current study was to examine the relationship between consumption aspirations, brand knowledge and customer decision making amongst the fast food sector of Pakistan. Results show consumption aspirations and brand knowledge are the determinant of customer decision making in fast food sector of Pakistan. The results are in accordance with the proposed hypothesis of the study, which shows that there is a significant relationship between consumption aspirations, brand knowledge and customer decision making. The Results of the study show that there is a significant association between consumption aspirations, brand knowledge and customer decision making. The fast food sector can get higher level of customer satisfaction and a higher number of customer base and market share through a higher level of brand knowledge and consumption aspiration of the customer. Over all, the results of the study show that there is a positive association between consumption aspirations, brand knowledge and customer decision making in the fast food sector of Pakistan.

\section{References}

Banerjee, S. \& Yancey, S. (2010). "Enhancing mobile coupon redemption in fast food campaigns. Journal of Research in Interactive Marketing, 4(2), 97-110.

Church, I. \& Newman, A. J. (2000). Using simulations in the optimization of fast food service delivery. British Food Journal, 102 (5/6), 398-405.

Davies, G. J., \& Smith, J. L. (2004). Fast food: dietary perspectives. Nutrition \& Food Science, 34(2), 80-82.

Dana, L. P., \& Dana, T. E. (1999). Fast food in Istanbul. British Food Journal, 10(5/6), 490-492.

Dixon, J. M., Hinde, S. J., \& Banwell, C. L. (2006). Obesity, convenience and "phood”. British Food Journal, 108(8), 634-645.

Darian, J. C., \& Cohen, J. (1995). Segmenting by consumer time shortage. Journal of Consumer Marketing, 12(1), 32-44. 
Eagle, L., \& Brennan,R. (2007). Beyond advertising: in-home promotion of “fast food. Young Consumers, 8(4), 278-288.

Fanning, J., Marsh, T., \& Stiegert, K. (2010). Determinants of US fast food consumption 19941998. British Food Journal, 112(1), 5-20.

Goyal, A., \& Singh, N.P. (2007). Consumer perception about fastfood in India: an exploratory study. British Food Journal, 109(2), 182-195.

Gilbert, G. R. (2006). A cross-industry comparison of customer satisfaction. Journal of Services Marketing, 20, 298-308.

Gilbert, G. R. , Veloutsou, C., Goode, M. M.H., \& Moutinho, L.(2004). Measuring customer satisfaction in the fast food industry: a cross-national approach. Journal of Services Marketing, 18(5),371-383.

Jones, P., Hillier, D., Shears, P., \& Clarke-Hill C.(2002). Customer Perceptions of Services Brands: A Case Study of the Three Major Fast Food Retailers in the UK”. Management Research News, 25(6/7), 41-49.

Kobayashi, F. (2010). Television viewing and fast food intake of American and Japanese college students. Nutrition \& Food Science, 40(2), 204208.

Kara, A., Kaynak, E., \& Kucukemiroglu, O.(1995). Marketing strategies for fast-food restaurants: a customer view. International Journal of Contemporary Hospitality Management, 7(4), 16-22.

Kara, A., Kaynak, E., \& Kucukemiroglu, O. (1997). Marketing strategies for fast-food restaurants: a customer view. British Food Journal, 99(9), 318-324.

Liu, C.M. (2000). A look at fastfood competition in the Philippines. British Food Journal., 102(2), 122-133.

Law, A. K.Y., Hui Y.V. \& Zhao, X. (2004). Modeling repurchases frequency and customer satisfaction for fast food outlets. International Journal of Quality \& Reliability Management, 21(5), 545-563.

Lee, M., \& Ulgado, F. M. (1997). Consumer evaluations of fastfood services: a cross-national comparison. The Journal of Services Marketing, 11(1), 39-52.

McCarthy, M., Brennan, M., Ritson, C. \& Boer, M.D. (2006). Food hazard characteristics and risk reduction behavior: The view of consumers on the island of Ireland. British Food Journal, 108(10), 875-891.

Pettigrew, S., \& Roberts, M. (2006). Mothers' attitudes towards toys as fast food premiums. Young Consumers, Quarter 3.

Pettigrew, S., \& Charters, S. (2006). Consumers' expectations of food and alcohol pairing. British Food Journal, 108(3), 169-180.

Price, S. (1997). The new fasces of the fast food market? The potential for consortia in pizza home delivery. International Journal of Contemporary Hospitality Management, 9(3), 101-109.

Qin, H., and Victor, R. P, (2009). Service quality, customer satisfaction, and behavioral intentions in fast-food restaurants. International Journal of Quality and Service Sciences, 1(1), 78-95.

Qin, H., Prybutok, V. R., \& Zhao, Q. (2010). Perceived service quality in fast- food restaurants: Empirical evidence from China. International Journal of Quality \& Reliability Management, 27(4), 424-437.

Rodgers, S. (2008). Technological innovation supporting different food production philosophies in the food service sectors. International Journal of Contemporary Hospitality Management, 20(1), 19-34.

Worsfold, D. (2006). HACCP workshops - practical guidance for small fast food businesses. Nutrition \& Food Science, 36(1), 32-42.

Zbib, I. J., Wooldridge, B. R. , Ahmed, Z. U. \& Benlian, S. (2010). Selection criteria of Lebanese consumers in the global snack food industry: country of origin perceptions. Journal of Consumer Marketing, 27(2), 139-156. 